\title{
Carceral Universals
}

Bob Gaucher

$\mathrm{O}$ ver the past quarter century, the coercive powers of western democratic states have continued to expand (Cohen, 1985), invading private spheres of family and everyday social life (Donzelot, 1979; Mauer \& Chesney-Lind, 2002; Hillyard \& Tombs, 2004), and reformulating health (e.g., transcarceration) and labour (e.g., prison industries) relations (Herivel and Wright, 2008). The coercive management of political dissent and class struggle, exemplified in mass imprisonment (Parenti, 1999; Garland, 2001; Wacquant, 2001), has been further legitimated by heightened rhetoric on national security and immigration (Buehl, 2006; Huckelbury, 2006). Globally, the universal carceral is represented in the displaced, brutalized, and interned populations produced by civil wars, foreign occupations, and natural disasters. The expansion and intensification of coercive powers is a global phenomenon, reflecting the fragility of social order and the authority of ruling elites in the $21^{\text {st }}$ century. The proliferation of new forms of carceral control is exemplified in the confinement of the Palestinian People (AlKilani, 2006).

Relationships of domination, powerlessness and resistance, still characterize the carceral experience. Breyten Breytenbach (1984), writing from a South African prison cell, prophetically noted:

When you are interested in prison accounts as a genre you will soon see that prisons are pretty much the same the world over. It is rather the peculiar relationship of power-repression which seems immutable, wherever you may hide. And when you scratch a little bit you will see that our century is stained by large scale and institutionalized acts and even policies of brutality in growing areas of the world. The tolerance is less; totalitarianism is on the increase. Never before has it become so all-important for all of us - especially for the most 'ordinary' citizen - to struggle with all the inventiveness at our disposal against the dehumanization of man. The least all of us can do - the marginal ones, the outcasts, the displaced persons, the immigrant workers, citizens of our various countries - is unite to expose all the intelligence services and spy organs and the security police and the secret societies of the world. Pipe dream! So much for universality (p. 339). 
The intensification and expansion of carceral control has been propelled by business management rationales (Christie, 1999) parading as penal policy (Hassine, 1995), and the successful commoditization of the marginalized and disenfranchised by the for profit prison industrial complex (Greene, 2002; Burton-Rose, Pens and Wright, 1998; Herivel and Wright, 2008). Since its inception in 1988, the JPP has sought "to bring the knowledge and experience of the incarcerated to bear upon ... academic arguments and concerns, and to inform public discourse about the current state of our carceral institutions" (Gaucher, 1988, p. 54). Throughout this issue, the transformative power of the penal institution and its dehumanization of the prisoner is illustrated and elaborated. The contributors speak to the universal carceral experience of survival in extreme situations. While prisoners' resistance is as universal as the carceral power-repression relationship that generates it, its forms reflect the conditions that pertain; from the extreme isolation of the control unit (Khaldun) to the forced labour of a Texas industrial farm (Odom). My colleagues in the field of criminology need to be reminded of the deteriorating, life threatening conditions that millions of prisoners across the globe endure daily. This issue does not require a discourse on the theoretical consideration of "governmentality" in the age of risk management and insecurity, but an exposé on the draconian degradation and destruction of human beings by their fellow citizens. Some people need to be reminded of the anguish and torment visited upon others in their name. This issue succeeds in accomplishing that task.

In "Broken Wing", Reginald Lewis sets the stage, evoking the drab, dank atmosphere of the prison yard, and portraying the spark of humanity generated by an encounter with the natural world. James Blau, in "New Boots", discusses the inevitable transformation of the prisoner into convict, and the unavoidable relationship to institutional convict culture. Like "normative behaviour" in open society, prisoner relationships and institutional convict culture have become increasingly instrumental. Under conditions of serious overcrowding and institutional crisis management (Hassine, 1995), survival demands it. In "The Hate Prison Breeds", the life of a long term Texas prisoner exemplifies the voyage that comes with the issuing of "convict boots". The inescapable domination of the total institution, its violence and brutality, the snakes and ladders life path of those cast into the perdition of imprisonment, lead to the socialization into the eternal convict identity. This is the world and state of being that is being forced upon countless youth. 
Lest we mistakenly disregard the active participation of prison authorities in the destructive transformation of the prisoner, Khalfani Malik Khaldun, in "The Psychology of Invisibility", maps the purposeful destruction of the outside social relations and social identity of the prisoner in control unit isolation. This separation of the isolated prisoner from all human contact is a means of breaking down all conceivable resistance (Jackson, 1983). This tactic is especially pernicious in light of the growing population of incarcerated mentally disabled in the prisons of the west, who make up a considerable proportion of control unit inhabitants. Phillip Horner elaborates on the social disappearance of prisoner as a form of identity theft, through the transfer of their roles as "father" to a state designated "Big Brother". The destruction of prisoners' ties to their families is understood as an aspect of the processes of isolating the designated "criminal". Ed Bowser extends this portrait of powerlessness in his discussion of the experience of a death in the family, while imprisoned. Here, as in all aspects of carceral life, the "crisis" management needs of the dominant institution supersede the human needs of those subjected to it.

This dehumanizing disregard extends to physical and mental health. Horner, Odom, Dey, Olson and Kunselman, all address the frightening, recurring problems with health care delivery in U.S. prisons. These carceral universals have worsened under conditions of mass imprisonment, overcrowding, and industrial management rationales (Elliott and Horii, 1994; Lewis, 1995; Stewart, 1997; Stewart and Durnford, 1997; Murphy, 2006). Noting the time tested pharmaceutical control approaches of mental hospitals, Horner, in "Prozac in Prison", discusses the prevalence of psychotropic drugs in U.S. prisons, in part reflecting the increased imprisonment of the mentally disabled (i.e., transcarceration). He reveals the underlying contradiction between the punitive purpose of prison regimes (see Huckelbury, 1997) and the provision of professional psychological counseling to address the consequent depression. Drugs fill the gap in the 'House of Pain'. Don Odom, "Mental Health Treatment in Texas Prisons: A Patient's Perspective", analyses the growth of transcarceration in Texas during George W. Bush's reign as Governor, and the current situation of criminalized mental patients. Based upon 30 years of first hand experience, Odom recounts the plight of the mentally disabled, from the bullying and violence of inmate guards, through the current dominance of prison regimes over health issues. Both Horner and Odom note the ubiquitous treatment 
given to prisoners designated for "suicide watch". "The suicide tank is shock treatment for suicidal prisoners. 'If you don't like your life now, we'll show you just how bad life can get."' (Horner). (see also, Elliott and Horii, 1994; Stewart and Durnford, 1997). Transcarceration is a growing phenomenon across western societies with estimates ranging from 20 to 40 per cent of prisoners in jurisdictions such as Canada, the U.S. and the U.K.

Eugene Dey's analysis in "Hepatitis C and the California Prisoner" highlights the contagious diseases that plague contemporary prison institutions. Beware of falling ill in prison! While medical attention in prisons is limited worldwide (e.g., see Hanna, 2005), currently the overwhelming numbers of prisoners, the crisis ridden expansion of prison facilities, and profit driven industrialization has spun the situation out of control in many jurisdictions, including Canada, the U.S. and the U.K. The health threat posed by these carceral incubators of treatment resistant disease stretches across continents, from Russia to Nigeria, Brazil and North America.

In "Acceptable Casualties", Bernadette Olson and Julie Kunselman provide a general indictment of the criminalization and incarceration of a rapidly increasing number of women prisoners in the U.S. Having worked in criminal justice prior to incarceration, Olson brings a unique perspective to her carceral experience. Despite the relatively short time spent incarcerated, Olson's account centers upon the transformative power of the penal institution and the consequent dehumanization of the prisoner in all facets of life, especially the enduring psychological trauma produced by this encounter.

"Monument" reflects on the official New York State plaque, located outside Attica State prison, commemorating the 11 staff who died during the riot of September, 1971. The absence of any notation of the 32 prisoners who also lost their lives is indicative of the social disappearance and disregard for the humanity of prisoners. It also represents the refusal of those in authority to take responsibility for the consequences of criminal justice and penal policy. In "The Redeemed Spirit of Stanley Tookie Williams", Dortell Williams proposes a monument of his own. Stanley Tookie Williams represents prisoners' abilities to overcome past mistakes and contribute to their societies, even on death row. Like James V. Allridge (Gaucher, 2005), he illustrated the contradiction between the discourse on rehabilitation and the unforgiving actuality of carceral custom. Both men were executed.

Kat Armstrong and Vicki Chartrand, in "Checking Out But Never Leaving", provide an historical analysis of the gender bias underlying female 
exclusion in Australia, establishing that the roots of contemporary control practices vis-à-vis women are located within Australia's penal colony past. Charles Huckelbury brings the analysis of this issue full circle in "NeoPrussian Politics: Absolutism in the USA", which provides a geo-political overview of contemporary social control in the U.S. He cuts through the mists of the insecurity rhetoric and the foul breath of dominant criminal justice discourse, exposing the agenda and absolutist style "democracy" of the current regime. Christie (1999) and others (Stern, 2002) have noted the global prominence and influence of the U.S. prison industrial complex, which continues to exacerbate the deterioration of social life and relations in societies across the globe. In a future of increased insecurity and political economic turmoil, control of dissent and resistance will remain the point of entry for the repressive management of populations and the reproduction of docile bodies.

The cover art is by Dusty Roads, an Australian Aboriginal artist, whom I met at Risdon Prison, Tasmania during the ICOPA XI conference in 2006. We are pleased to feature the work of this noted artist.

I am pleased by the Response to this issue, and the affirmation it provides for our efforts in producing the JPP. While writing from the sidelines of academia, contributors to the JPP have continued to identify the developing issues in criminal justice and penal practices, and analyze their impacts and predicted future trajectories, long before academics have discovered and responded to the most pressing problems. Throughout my involvement with the JPP and writers in prison, I have always been struck by their insight into and astute reading of the human condition. I would like to thank you all for motivating me to stay the course. After 45 years of resistance and agitation, it is difficult to be hopeful and not let cynicism invade my thinking and life. Certainly the situation globally is much worse than we could have imagined in the hopeful 1960s and 1970s, when I first became involved. Over decades of correspondence with so many long termers and lifers, their resilience, hopefulness, and courage have stood out. How can a people, who have spent decades in brutalizing conditions and often endured years of isolation, still believe in humanity and find the strength to continue to struggle and engage the world that has cast them into perdition? I know that there are many righteous and decent human beings imprisoned across the world, and I applaud their efforts. To every prisoner with whom I have corresponded, my heartfelt thanks. Working for the past 25 years at the (recently christened) 
Stockwell Day School of Criminology at the University of Ottawa, has often been a disillusioning experience. Like me, many students have thoroughly appreciated your efforts and ability to cut through the punitive rhetoric to reveal the human side of this current carceral binge.

This will be the last issue of the JPP that I produce. A group of young scholars, raised on abolitionist theory and committed to social justice, will soon be taking over the day to day operations of the JPP. They have contributed book reviews to this issue, and will continue the ethnographic work that started at the ICOPA III conference in Montréal, Quebec in 1987, and led to the creation of the JPP. Their contributions to the penal abolitionist movement are featured in the "Call For Papers" included in this issue. Please give them the support you offered me throughout my sojourn as an editor.

\section{REFERENCES}

Al-Kilani, Sami (2006) "Days of Ansar 3: A Pulsing Thorn in my Heart", Journal of Prisoners on Prisons, Volume 15(1), p. 28-38.

Al-Kilani, Sami (2006) "Until Further Notice”, Journal of Prisoners on Prisons, Volume 15(1), p. 24-27.

Breytenback, Breyten (1984) The True Confessions of an Albino Terrorist. London: Faber and Faber Ltd.

Buehl, Roger (2006) "What Did you Expect?" Journal of Prisoners on Prisons, Volume 15(1), p. 1-3.

Burton-Rose, Daniel, Dan Pens, and Paul Wright (editors) (1998) The Celling of America: An Inside Look at the U.S. Prison Industry. Common Courage Press.

Christie, Nils (1999) Crime Control As Industry. London: Routledge.

Cohen, Stanley (1985) Visions of Social Control. Cambridge: Polity Press.

Donzelot, Jacques (1979) The Policing of Families. New York: Pantheon.

Elliott, Liz and Gayle K. Horri (editors) (1994) Journal of Prisoners on Prisons, Volume $5(2)$.

Garland, David (editor) (2001) Mass Imprisonment: Social Causes and Consequences. London: Sage Publications Ltd.

Gaucher, Bob (1988) "The Prisoner As Ethnographer: The Journal of Prisoners on Prisons", Journal of Prisoners on Prisons, Volume 1(1), p. 49-62.

Gaucher, Bob (editor) (2002) Writing As Resistance: The Journal of Prisoners on Prisons Anthology (1988-2002). Toronto: Canadian Scholars Press Inc.

Gaucher, Bob (2005) "Victims - Both Sides: A Tribute to James V. Allridge III (19622004)", Journal of Prisoners on Prisons, Volume 14(1), p. 101-107.

Greene, Judith (2002) "Entrepreneurial Corrections: Incarceration As a Business Opportunity" in M. Mauer and M. Chesney-Lind (editors) Invisible Punishment: The Collateral Consequences of Mass Imprisonment. New York: The New Press. 
Hassine, Victor (1995) "Runaway Prison or Mr. Smith Goes to Harrisburg”, Journal of Prisoners on Prisons, Volume 6(1), p. 5-10.

Herivel, Tara and Paul Wright (editors) (2008) Prison Profiteers: Who Makes Money Off Mass Incarceration. New Press.

Hillyard, Paddy, Christina Pantazis, Steve Tombs, and David Gordon (editors) (2004) Beyond Criminology: Taking Harm Seriously. Black Point, Nova Scotia: Fernwood Publishing.

Huckelbury, Charles (1997) “On Being a Nigger”, Journal of Prisoners on Prisons. Volume 8 ( $1 \& 2)$, p. 9-17.

Huckelbury, Charles (2006) "Made in the U.S.A.: A Postmodern Critique", Journal of Prisoners on Prison, Volume 15(1), p. 4-16.

Jackson, Michael (1983) Prisoners of Isolation: Solitary Confinement in Canada. Toronto: University of Toronto Press.

Lewis, R. Baz (1995) "Medical Horror in a British Prison", Journal of Prisoners on Prisons, Volume 6(1), p. 39-40.

Mauer, Marc and Meda Chesney-Lind (editors) (2002) Invisible Punishment: The Collateral Consequences of Mass Imprisonment. New York: The New Press.

Murphy, Brenda (2006) "Mother's Day", Journal of Prisoners on Prisons. Volume 15(1), p. 20-23.

Stern, Vivien (2002) "The International Impact of U.S. Policies", in Mauer and ChesneyLind (editors), p. 279-292.

Stewart, Melissa (1997) "Prison for Women's Invisible Minority", Journal of Prisoners on Prisons, Volume 8 (1 \& 2), p. 91-103.

Stewart, Melissa and P. Durnford (1997) "Suicide: The Challenges Faced by Female Federal Prisoners", Journal of Prisoners on Prisons, Volume 8 (1 \& 2), p. 79-90.

Wacquant, Loic (2001) "Deadly Symbiosis: When Prison and Ghetto Meet and Mesh", in Garland (editor) (2001). 